\title{
INTERNAL BENCHMARKING IN RETAILING WITH DEA AND GIS: THE CASE OF A LOYALTY-ORIENTED SUPERMARKET CHAIN
}

\author{
Amparo BAVIERA-PUIG $\mathbb{C D}^{*}$, Tomás BAVIERA (i), \\ Juan BUITRAGO-VERA ${ }^{\circledR}$, Carmen ESCRIBÁ-PÉREZ ${ }^{\circledR}$ \\ Department of Economics and Social Sciences, Universitat Politècnica de València, \\ Valencia, Spain
}

Received 12 March 2019; accepted 30 March 2020

\begin{abstract}
Data Envelopment Analysis (DEA) is a relative measure of efficiency applied to a set of decision units and is being used more and more frequently in the supermarket sector. Nonetheless, given how strongly the sector's financials depend on demand, companies need to combine this measurement with trade area information to best manage corporate efficiency. In this paper, the proposal consists of integrating DEA with a clearly articulated, structural typology so that supermarkets, based on their particular characteristics, can determine which variables are most critical for improving their efficiency. This methodology has been validated in the case of one of Spain's five largest supermarket chains. A principal component analysis and a classification analysis were carried out on a series of internal management variables from 61 locations for which DEA had been used to calculate efficiency and to which multiple trade area variables were added using GIS. Some of them are related to the loyalty scheme membership programme. These latter variables described the implantation of the loyalty scheme member programme and were revealed as key elements for the efficiency of the supermarket. This methodology provides marketing profiles that are more adapted to local circumstances, thus allowing companies to set better internal benchmarking objectives.
\end{abstract}

Keywords: efficiency, Data Envelopment Analysis (DEA), Geographical Information Systems (GIS), multivariate analysis, benchmarking, trade area, geomarketing.

JEL Classification: M31, C67, L81.

\section{Introduction}

Data Envelopment Analysis (DEA) has been increasingly used as a method to determine the relative efficiencies of a set of organisational units when there are multiple inputs and outputs (Charnes et al., 1978; Emrouznejad \& Yang, 2018). DEA is a data-dependent tool that identifies the most efficient units within a set. The final score classifies the units based on the various results obtained and the available resources (Nitkiewicz et al., 2014). In parallel,

\footnotetext{
${ }^{\star}$ Corresponding author. E-mail: ambapui@upv.es
} 
there has been a rapid expansion in the use of loyalty scheme membership initiatives. This type of programme is not only used as a promotional tool but also as a way to access a large quantity of customer-specific data (Byrom et al., 2001).

Nevertheless, in the case of supermarkets, an efficiency evaluation tool such as DEA could leave out a crucial aspect for sales: the establishment's location ( $\mathrm{Li} \& \mathrm{Liu}, 2012)$. Population density and the distance from competing supermarkets may influence the efficiency score, as the sector's financial results strongly depend on demand (Roig-Tierno et al., 2018). Consequently, the benchmark provided by DEA in this type of business could lead to poorlyfocused decisions, as it fails to sufficiently consider these factors. One way to solve this problem is to use Geographical Information Systems (GIS) to incorporate an efficiency analysis of the supermarket's trade area. A trade area can be defined as the geographic area in which a retailer attracts customers and generates sales during a specific period (Applebaum \& Cohen, 1961). In the case of a loyalty-oriented supermarket chain, the loyalty scheme cards offer high valuable information about the customers, which can also be incorporated. Furthermore, these loyalty scheme membership programmes also depend on the supermarket's trade area (Meyer-Waarden \& Benavent, 2006).

Therefore, the aim of this research is to create a classification system for supermarkets taking into account the local market in the evaluation of the store's efficiency, including some data provided by the loyalty scheme cards. It will be able to provide highly valuable information for better chain management as an internal benchmarking tool. Indeed, within each group made up of similar establishments, the most efficient one can be used as a reference so that the measures proposed for increasing efficiency are better tailored to the specific local circumstances of each group. As such, the company's overall vision is combined with each sales unit's geo-demographic characteristics. In this way, the DEA-based benchmarking process proposed by Donthu, Hershberger, and Osmonbekov (2005) can be improved upon.

This paper is structured as follows: first, the concept and effects of a loyalty scheme membership programme are introduced and the most recent studies that have applied this efficiency measure (DEA) to the retail sector are examined. Second, the research questions and methodology are discussed. Then, a typological study is applied to a chain of Spanish supermarkets. Lastly, the implications and conclusions of the research are presented.

\section{Theoretical background}

\subsection{Loyalty-oriented retailers}

Loyalty scheme membership programmes constitute an important customer relationship management tool, adopted by many industries (Kang et al., 2015). Meyer-Waarden (2008) defined a loyalty scheme membership programme as an integrated system of marketing actions whose objective is to make customers more loyal by developing tailored relationships with them. In the retailing sector, consumers usually have multiple choices. This is a problem for the retailers, as they have to find out how to gain a greater share of consumer purchases in comparison with their competitors. Meyer-Waarden (2007) found that loyalty schemes have positive effects on customer lifetimes and share of consumer expenditures, as long 
as the same consumer does not have multiple loyalty card memberships of geographically close retailers. In this case, the lifetime is reduced. Instead, the higher the share of consumer expenditures in a store, the longer the lifetime duration will be. Therefore, loyal customers can be defined as those with a relatively high share of expenditure, engaged in a long-term relationship with the retailer (Kumar \& Shah, 2004).

Much research has been done on the effects of loyalty scheme membership programmes on customer satisfaction, trust and loyalty. Kim, Lee, Choi, Wu, and Johnson (2013) discovered that monetary savings, entertainment and social benefits were found to be positive predictors of this kind of programme. Mimouni-Chaabane and Volle (2010) developed a scale to measure the perceived benefits of loyalty scheme membership programmes. Other authors focused on the importance of consumer's perception of status and reward exclusivity (Drèze \& Nunes, 2009; Steinhoff \& Palmatier, 2016). However, the choice of retail outlet is guided by other elements than the loyalty scheme membership programme. Meyer-Waarden and Benavent (2006) pointed out the competitive position, proximity, store size and the store's relative isolation from other retail outlets, among other factors. So, retailing greatly depends on the establishment's location. From the company perspective, authors have studied different indicators. For example, Chaudhuri, Voorhees, and Beck (2019) analysed the effect that a loyalty scheme membership programme has on the company's sales and gross profits. Kumar and Petersen (2005) examined their effect on profitability, customer equity and shareholder value, while Leenheer, Van Heerde, Bijmolt, and Smidts (2007) focused on share-of-wallet.

Despite all previous studies, three large gaps remain in the literature. First, the importance of implementing the loyalty scheme membership programme within the trade area of the retailer and its effect on efficiency has not been analysed yet. Second, so far, no author has linked loyalty scheme membership programmes to efficiency and these programmes have not been incorporated into benchmarking processes, where they could be a key tool in retailer management. Finally, no studies have been found that geolocate information from loyalty scheme cards to assess their potential. On the loyalty card application form, customers provide their address. Consequently, all data obtained from loyalty card transactions can be related to a position in a map, as they have a geographical dimension not exploited until now. Byrom et al. (2001) pointed out the geographical dimension of loyalty scheme card data and proposed some variables to use. As an exception, Roig-Tierno, Baviera-Puig, Buitrago-Vera, and Mas-Verdu (2013) and Baviera-Puig, Buitrago-Vera, and Escribá-Pérez (2016) geolocated the information provided by loyalty scheme cards in order to find the best location for new openings. In this article, loyalty scheme membership programmes are related with efficiency, using the DEA as an efficiency measure. In turn, the intention is to incorporate variables from both the management and the retailer's trade area (using GIS), given their influence, to develop an internal benchmarking process. Some of these variables are collected from the data provided by the loyalty scheme cards.

\subsection{Efficiency analysis in retailing}

DEA has been widely used as a measure of efficiency in the retail sector. Yu and Ramanathan (2008) applied DEA methodology in their study on the distribution sector in the United 
Kingdom. The efficiency measures allowed them to perform a longitudinal analysis of the sector and evaluate how the implementation of various technologies affected efficiency. In the United States, Mostafa (2009) compared traditional statistical models with global analysis models, such as DEA, as applied to the distribution sector. DEA has also revealed a lack of efficiency in management and investment in the Indian distribution sector (Gandhi \& Shankar, 2014). Uyar, Bayyurt, Dilber, and Karaca (2013) used DEA to determine why some bookstores are more efficient than others. In the same way, Tat Keh and Chu (2003) focused on grocery stores and Patel and Pande (2013) focused on the pharmacy sector.

Moreno (2010) examined the efficiency of the European distribution sector in general. First, he analysed the countries separately to draw up each one's efficiency frontier, and then compares the countries, concluding that the differences among countries may be due to different government regulations. In Portugal, Barros and Alves $(2003,2004)$ analysed the efficiency and productivity of supermarkets and hypermarkets. In Spain, Sellers-Rubio and Mas-Ruiz (2006) used DEA to point out a series of inefficiencies in the Spanish supermarket sector. A few years later, the researchers carried out a more comprehensive study in which they accounted for several factors that affected efficiency, such as the variety of the supermarket's stock and the wages it pays (Sellers-Rubio \& Mas-Ruiz, 2009). DEA results are also useful for tracking the evolution of efficiency over time in a particular region. In that vein, De Jorge (2006) confirmed a fall in technical efficiency in the Spanish distribution sector after the process for awarding opening licences was transferred to the autonomous communities in 1994.

Corporate (technical or production) efficiency can be defined as the ability of a firm to produce the most output with a given amount of inputs (Zheka, 2005; Hanousek et al., 2015). In this case, corporate efficiency is understood as the ability of the firm to manage the supermarkets in order to obtain the highest sales. The management variables used by the previous authors in DEA-based studies are shown in Table 1. The output variable most used is sales. As input variables, authors commonly use information related to employees, store size and age of outlet, among others. Nevertheless, in addition to the supermarkets' internal management, it is also essential to consider the characteristics of the establishments' trade area. The number of people living near the supermarket or the proximity of competitors can greatly affect demand (Cachero-Martínez \& Vázquez-Casielles, 2017). Moreover, when it comes to establishing a benchmarking process, the same demands cannot be made of premises with completely different trade area characteristics. These local factors have been included in DEA studies on supermarkets by very few authors.

Using DEA and GIS together could improve management in business units with a strong link to the trade area. GIS is a system designed to capture, store, manipulate, analyse, manage and present spatial or geographic data. In other words, GIS can transform the spatial data into useful information (Tomlinson, 2007). Nowadays, GIS offers a wide range of possibilities to obtain more detailed socio-demographic and competition information on the trade area (Goss, 1995; Harris et al., 2005). A study on Monterey-Salinas Transit bus lines, in Monterey County, California, used corporate-level efficiency information along with the GIS-obtained demographic profiles of the areas covered by each line (Lao \& Liu, 2009). These tools' contributions allowed the researchers to classify the bus lines to study how to improve 
Table 1. Management variables used in DEA-based studies in retailing (source: own creation)

\begin{tabular}{|c|c|c|c|}
\hline Author & Year & Input variables & Output variables \\
\hline Tat Keh and Chu & 2003 & $\begin{array}{l}\text { Accessibility, Assortment, Assurance of product } \\
\text { delivery, product information, ambience }\end{array}$ & Sales revenue \\
\hline Barros and Alves & 2003 & $\begin{array}{l}\text { Area of outlets, age of outlet, number of points } \\
\text { of sale, inventory, full-time employees, part- } \\
\text { time employees, labour cost, absenteeism, } \\
\text { other costs }\end{array}$ & $\begin{array}{l}\text { Operational results, } \\
\text { sales }\end{array}$ \\
\hline Barros and Alves & 2004 & $\begin{array}{l}\text { Number of full-time equivalent employees, } \\
\text { labour cost, number of checkout lines, stock, } \\
\text { other costs }\end{array}$ & $\begin{array}{l}\text { Operational results, } \\
\text { sales }\end{array}$ \\
\hline $\begin{array}{l}\text { Sellers-Rubio and } \\
\text { Mas-Ruiz }\end{array}$ & 2006 & Capital, outlets, employee & Profit, sales \\
\hline De Jorge & 2006 & Employees, fixed assets, spending & Sales \\
\hline $\begin{array}{l}\text { Yu and } \\
\text { Ramanathan }\end{array}$ & 2008 & $\begin{array}{l}\text { Total assets, employees, shareholder funds, } \\
\text { head office location, years of incorporation, } \\
\text { types of ownership, retail characteristics, legal } \\
\text { form }\end{array}$ & $\begin{array}{l}\text { Profit before taxation, } \\
\text { turnover }\end{array}$ \\
\hline Mostafa & 2009 & Assets, employees & $\begin{array}{l}\text { Market value, revenue, } \\
\text { earning per share }\end{array}$ \\
\hline $\begin{array}{l}\text { Sellers-Rubio and } \\
\text { Mas-Ruiz }\end{array}$ & 2009 & $\begin{array}{l}\text { Number of employees, store size, } \\
\text { average inventory investment per square metre, } \\
\text { average annual wage level per employee, age }\end{array}$ & Sales \\
\hline Moreno & 2010 & Fixed assets, employees, stock, labour costs & $\begin{array}{l}\text { Operational results, } \\
\text { sales revenue }\end{array}$ \\
\hline $\begin{array}{l}\text { Uyar, Bayyurt, } \\
\text { Dilber, and } \\
\text { Karaca }\end{array}$ & 2013 & $\begin{array}{l}\text { Store size, population, stock, number of } \\
\text { employees, } \\
\text { other costs }\end{array}$ & Sales, profit \\
\hline Patel and Pande & 2013 & $\begin{array}{l}\text { Store size, operating expenses, age of the store, } \\
\text { location of the store }\end{array}$ & Sales, footfalls \\
\hline $\begin{array}{l}\text { Gandhi and } \\
\text { Shankar }\end{array}$ & 2014 & Labour cost, employees & Sales, profit \\
\hline
\end{tabular}

their resource management according to the surrounding population. Specifically, the authors identified those bus lines which were performing well, those to be supported and subsidised and those to be expanded due to the high level of potential demand. Benchmarking yields information and enables agility and accuracy in the strategy setting process (Herranz et al., 2017).

Supermarkets, too, greatly depend on the nearby population. In addition, supermarkets face increasingly fierce competition (Pantano et al., 2018). As a result, both variables (population and competitors) have to be taken into account. Thanks to the GIS, the population and competitors in the trade area of each supermarket can be determined. Integrating corporate-level efficiency information obtained through DEA (management variables) with GIS-obtained data (trade area variables) could therefore be particularly useful in creating locally-adapted benchmarking processes (Vyt \& Cliquet, 2017). In this case, the supermarket 
chain also has additional information thanks to the loyalty scheme, a variable which has not been used until now. Specifically, the variables collected from the data provided by the loyalty scheme cards are percentage of purchases made by loyalty scheme members, average loyalty scheme member purchase in the trade area and loyalty scheme member market penetration in the trade area (Byrom et al., 2001; Roig-Tierno et al., 2013; Baviera-Puig et al., 2016). Analysing the relevance of these variables in DEA-based studies and internal benchmarking processes is the gap to be filled in the current research.

\subsection{Research questions}

This research proposes incorporating geo-demographic trade area characteristics into DEAbased analysis of food distribution chains. It is expected that population data and the presence of relatively nearby competitors can affect a supermarket's efficiency (Ingene, 1984; Goldman, 1992; Li \& Liu, 2012). However, implementation of the loyalty scheme membership programme in the trade area of the supermarket can also affect its efficiency (MeyerWaarden \& Benavent, 2006). Given the lack of evidence in this kind of management strategy, this study aims to address this gap. The first research question will face the relationship between corporate efficiency (using the DEA as an efficiency measure) and one of the critical issues for any supermarket whose strategy focuses mainly on a loyalty scheme member programme.

RQ1: Will the supermarket's DEA-based corporate efficiency be correlated with the average loyalty scheme member purchase in its trade area?

Donthu et al. (2005) recommended DEA to identify the best performers and set goals for improvement in benchmarking processes. It can reasonably be expected that, if geodemographic trade area characteristics (Goss, 1995; Grewal et al., 1999; Baviera-Puig et al., 2016; Neves Bezerra de Melo et al., 2018) and loyalty scheme member programme data are incorporated, the study of potential improvements in the supermarket group's management will be more applicable to each individual establishment. Given that the DEA reveals which supermarkets most efficiently manage resources, these establishments are likely to be concentrated in one group. In light of this idea, the following research question is proposed:

RQ2: In a group of supermarkets with similar management, corporate efficiency and trade areas, will those establishments lying on the efficiency frontier, according to the DEA, be in the same group?

Noordhoff, Pauwels, and Odekerken-Schröder (2004) demonstrated that loyalty scheme member programmes do indeed have an impact on attitudinal as well as behavioural store loyalty. Consequently, the role played by loyalty scheme cards could be relevant when establishing differences and goals between groups of supermarkets to perform internal benchmarking. Thanks to the GIS, the information collected by the loyalty scheme card data can be located on a virtual map. These variables can then be used not only as management variables, but also as geo-demographic characteristics. The variables associated with the loyalty scheme membership programme proposed are percentage of purchases made by loyalty scheme members, average loyalty scheme member purchase in the trade area and loyalty scheme member market penetration in the trade area. For this reason, the last research question is suggested: 
RQ3: Will the variables associated with the loyalty scheme membership programme pinpoint significant differences between the different groups of supermarkets obtained for internal benchmarking?

\section{Methodology}

In this research, the DEA model was applied first. Next, a series of statistical analyses were carried out to evaluate each of the research questions.

\subsection{DEA model}

Data Envelopment Analysis is a linear programming method that measures the relative efficiency of groups of decision-making units (DMU). The model is based on the hypothesis that each DMU requires resources (inputs) to produce goods or services (outputs). It is a data-driven, non-parametric, non-stochastic methodology that evaluates the DMUs' conversion of inputs into outputs. Using the DEA model, effective behaviours can be identified, determining which units employ them, and drawing an efficiency frontier to track each DMU's conversion of inputs to outputs (Charnes et al., 1978).

Each unit's relative efficiency is calculated by comparing its production function with the estimated production frontier. In this way, each DMU's performance is compared directly with the best performance of each pair or combination of pairs. This model does not require a function to relate inputs and outputs (Sanjuan et al., 2011). Moreover, the inputs and outputs can have different units. The model also allows the user to include various outputs in the analysis and frees him/her from having to select just one measure of efficiency, a feature that distinguishes this model from other regression-based tools (Zhu, 2014).

The DEA model accounts for returns to scale, that is, the relationship between increases in production (output) and increases in the factors of production (input). When increases in the production factors lead to the same percentage increases in production, the returns to scale are constant (CRS), whereas when increases in the production factors lead to a different percentage increase in production, the returns to scale are variable (VRS). In this study, the law of diminishing returns, which holds that as the number of variable factors increases, so does production, cannot be applied because the supermarkets hold the number of factors steady (the input variables). As the increase in inputs is limited, so too is the increase in outputs. Consequently, the choice was made to assume the returns to scale to be constant.

Furthermore, the model can be either input- or output-oriented. Whereas with an inputoriented model the linear programming model is configured to determine when a company can reduce input, if used efficiently, to obtain the same level of output, an output-oriented model calculates the potential improvement in output given the existing level of input (Banker et al., 1984). In this case, an output-oriented model was used, as it was assumed that the supermarkets are subject to market demand and the inputs are controlled by the DMUs, which purport to maximise output and minimise input to obtain greater profits (Vyt \& Cliquet, 2017). 
Mathematically, the model is defined as follows:

$$
\begin{gathered}
\operatorname{Max} \mu \\
\text { s.t. } \sum_{j} \lambda_{j} x_{j m} \leq x_{j 0 m} ; m=1 \ldots M, \\
\sum_{j} \lambda_{j} y_{j n} \geq \mu y_{j 0 n} ; n=1 \ldots N, \\
\lambda_{j} \geq 0 ; j=1 \ldots J .
\end{gathered}
$$

In which: $\mu=$ objective function, relative efficiency; $\lambda_{j}=$ weight vector of unit $j ; m=$ total number of inputs; $n=$ total number of outputs; $j=$ number of decision-making units; $x_{j m}=$ input $(m)$ of unit $j ; y_{j n}=$ output $(n)$ of unit $j$.

\subsection{Multivariate analysis}

To address RQ1, an interdependence analysis was carried out. The reason for this approach is the difficulty of isolating the corporate efficiency variable in this complex scenario. Hence, a Principal Component Analysis (PCA) was performed based on the wide range of variables considered. As the aim is to identify homogeneous supermarket profiles for RQ2, a structural typology was developed based on the present database (López-Roldán, 1996). This methodology involves the previous PCA, followed by a classification analysis (CA) to group similar supermarkets in order to answer RQ2 (Felício \& Galindo, 2015). Finally, an ANOVA was performed to check if there were significant differences between groups for some variables to response RQ3 (López-Roldán \& Fachelli, 2016). All the calculations were performed using the SPSS software.

\section{Case study}

\subsection{Data and variables}

The DMUs are the 61 supermarkets that make up one of Spain's top five national chains, one of whose primary goals is to achieve loyalty among its loyalty scheme members. Given that the DEA model seeks to minimise variables of input to maximise those of output, certain variables had to be adapted. These input and output variables were chosen after consultation with management and supported by the bibliography. To perform the DEA, the following input variables were used (Donthu \& Yoo, 1998):

1. Loyalty scheme member purchases indicates the percentage of purchases made by loyalty scheme members during the given year. To obtain this figure for the DEA model, data from loyalty scheme member cards were used to determine total purchases made by loyalty scheme members, and then divided this figure by the supermarket's total sales to arrive at a percentage. This figure was then subtracted from $100 \%$ to obtain non-loyalty scheme member purchases, which was used in the DEA model. This process is called reverse scoring and is used in the literature by Lewis and Sexton (2004) and C. Brønn and P. S. Brønn (2005).

2. The supermarket's floor space in square metres (Barros \& Alves, 2003; Sellers-Rubio \& Mas-Ruiz, 2009; Uyar et al., 2013; Patel \& Pande, 2013). 
3. Parking is the supermarket's number of parking spots (Tat Keh \& Chu, 2003).

4. Losses from perishable goods indicates losses, in euros, each supermarket suffered in a given year due to throwing away expired perishable goods (Álvarez-Rodríguez et al., 2019).

5. Checkout lines is the number of cash registers by the supermarket's exit (Barros \& Alves, 2004).

6. Age refers to how long the supermarket has been open. The inverse was used in the DEA model, given that the older a supermarket is, the more likely it is to be known by the public (Barros \& Alves, 2003; Sellers-Rubio \& Mas-Ruiz, 2009; Patel \& Pande, 2013).

The output variables were as follows (Kato, 2015; Neves Bezerra de Melo et al., 2018):

1. Each supermarket's total sales for that year in euros (2017);

2. Sales per square metre (2017).

Neither employees nor wages were considered as variables, as the chain's labour patterns are homogeneous throughout its establishments. The chain's top management assumed that these both variables were similar for each store. Based on these two sets of variables (input and output), DEA was used to calculate corporate efficiency. The efficiency of the outputoriented model suggests that as output increases, $\mathrm{DMU}_{0}$ becomes less efficient. In calculating each $\mathrm{DMU}_{0}$ 's relative efficiency as the inverse this variable ranges from 0 to 100 , with a score of 100 assigned to the most efficient establishments.

Lastly, the trade area variables, obtained using the ArcGis10 software, were as follows (Thomas et al., 1998; Yoo et al., 1998; Byrom et al., 2001; Barros, 2006; Meyer-Waarden \& Benavent, 2006; Li \& Liu, 2012; Vyt \& Cliquet, 2017):

1. Population within $400 \mathrm{~m}$ indicates the estimated number of people living within a 400-metre radius of the supermarket, obtained from census housing data.

2. Average loyalty scheme member purchase within $400 \mathrm{~m}$ indicates the purchases in euros made by the supermarket's loyalty scheme members who live within a 400 -metre radius of the establishment, a figure obtained from loyalty scheme card data.

3. Loyalty scheme member market penetration within $400 \mathrm{~m}$ refers to the number of loyalty scheme members who live within a 400 -metre radius of the supermarket as a percentage of the total population within the same area.

4. Primary competitor establishments within $500 \mathrm{~m}$ is the number of supermarkets owned by the primary competitor within a 500-metre radius, a criterion established by Roig-Tierno et al. (2013). This information on the competitors came from the Nielsen database (2018).

5. Distance from the nearest competitor is the closest distance from the primary competitor.

Once the statistics were obtained from the different databases cited (census housing data, loyalty scheme card data and Nielsen database), GIS allowed the information to be located on a virtual map. Then, it was possible to draw up a buffer zone of the radius specified (400 $\mathrm{m}$ or $500 \mathrm{~m}$ ) and obtain the final variables. A $400 \mathrm{~m}$ distance was used as a reference point for population, average loyalty scheme member purchase and loyalty scheme member market 
penetration, as Baviera-Puig et al. (2016) found that more than $80 \%$ of the supermarket's loyalty scheme member-customers lived within a 400-metre radius of said supermarket. U1timately, this study's database consisted of 61 supermarkets described by 14 variables, of which there were six inputs, two outputs, five trade area variables, and, finally, the measure of corporate efficiency (Table 2). It should be noted that of all these variables, three refer to loyalty scheme card data. This is due to the importance that this chain of supermarkets gives to this card, representing a key element in the strategy of the supermarket chain.

Table 2. Descriptive statistics on the variables (source: own creation)

\begin{tabular}{|c|c|c|c|c|c|}
\hline & Variables & Maximum & Minimum & Average & $\begin{array}{l}\text { Standard } \\
\text { deviation }\end{array}$ \\
\hline \multirow{6}{*}{ INPUT } & $\begin{array}{l}\text { Purchases made by } \\
\text { loyalty scheme members } \\
\text { (\%) }\end{array}$ & 86.66 & 42.22 & 67.90 & 10.08 \\
\hline & $\begin{array}{l}\text { Supermarket's floor space } \\
\text { area }\left(\mathrm{m}^{2}\right)\end{array}$ & 1,855 & 560 & $1,098.39$ & 357.30 \\
\hline & Number of parking spots & 300 & 0 & 35.84 & 52.88 \\
\hline & $\begin{array}{l}\text { Losses from perishable } \\
\text { goods }(€)\end{array}$ & $60,562.35$ & $12,901.14$ & $32,303.15$ & $10,981.21$ \\
\hline & Checkout lines & 4 & 1 & 1.57 & 0.62 \\
\hline & $\begin{array}{l}\text { Age of supermarket } \\
\text { (years) }\end{array}$ & 35 & 2 & 10.98 & 6.77 \\
\hline \multirow{2}{*}{ OUTPUT } & Total sales $(€)$ & $10,297,781.9$ & $1,026,276.27$ & $4,068,844.85$ & $1,910,530.57$ \\
\hline & Sales per square metre & $8,404.76$ & 771.64 & $3,888.55$ & $1,748.22$ \\
\hline EFFICIENCY & Corporate efficiency & 100.00 & 14.00 & 66.89 & 25.45 \\
\hline \multirow{5}{*}{ TRADE AREA } & Population within $400 \mathrm{~m}$ & 22,575 & 1,973 & $12,812.20$ & $5,014.03$ \\
\hline & $\begin{array}{l}\text { Average loyalty scheme } \\
\text { member purchase within } \\
400 \mathrm{~m}(€)\end{array}$ & $1,641.12$ & 188.33 & $1,009.41$ & 319.40 \\
\hline & $\begin{array}{l}\text { Loyalty scheme member } \\
\text { market penetration } \\
\text { within } 400 \mathrm{~m}(\%)\end{array}$ & 38.18 & 3.93 & 16.34 & 8.00 \\
\hline & $\begin{array}{l}\text { Primary competitor } \\
\text { establishments within } \\
500 \mathrm{~m}\end{array}$ & 4 & 0 & 1.34 & 1.00 \\
\hline & $\begin{array}{l}\text { Distance from nearest } \\
\text { competitor }(\mathrm{m})\end{array}$ & 890.92 & 120.18 & 396.31 & 172.96 \\
\hline
\end{tabular}

\subsection{Corporate efficiency and loyalty scheme membership programme}

First, a PCA was performed with all the variables (input, output, corporate efficiency and trade area). After performing the analysis with these 14 variables, a measure of sampling adequacy of 0.401 was obtained for the floor space variable. As it was less than 0.5 , the decision was taken to exclude it from the PCA (López-Roldán \& Fachelli, 2016). After perform- 
ing the analysis with the remaining 13 variables, the variable loyalty scheme member market penetration within $400 \mathrm{~m}$ also had a measure of sampling adequacy less than 0.5 , thus ruling out this variable.

The 12-variable PCA obtained satisfactory measures, per López-Roldán and Fachelli (2016). The correlation matrix determinant was 0.002 and the Bartlett sphericity test was significant. Consequently, the hypothesis that the variables were independent was rejected. The Kaiser-Meyer-Olkin measure of sampling adequacy was 0.759 . The smallest measure of sampling adequacy for each variable was 0.510 . With these two pieces of data, it was confirmed that the relationship among the variables was strong enough to carry out a PCA.

Lastly, after conducting the PCA, four factors explained $72.92 \%$ of the total variation. Factor loadings, obtained after applying Kaiser's varimax rotation, appear in columns 2 to 5 of Table 3. Factor 1 explains $38.45 \%$ of the variance, and the variables with the greatest weight are sales per square metre, total sales, average purchase of loyalty scheme members within $400 \mathrm{~m}$, and corporate efficiency. This factor contains the four types of studied variables: input (the age of the supermarket), the two outputs, a trade area variable (average purchase of loyalty scheme members within $400 \mathrm{~m}$ ), and corporate efficiency. Together, they represent an axis that reflects the four fundamental aspects: corporate efficiency, sales figures, the average purchase of loyalty scheme members in the trade area, and the supermarket's age. The fundamental characteristics of this axis are considered to be sales figures and age.

Factor 2 explains $15.34 \%$ of the total variance. In this factor, the strongest variables are primary competitor establishments within $500 \mathrm{~m}$, the distance from the nearest competitor, and population within $400 \mathrm{~m}$, all of which correspond with the trade area. Factor 3 explains 11\% of the total variance, the major variables therein being checkout lines and purchases made by loyalty scheme members (\%). Factor 4 explains $8.13 \%$ of the total variance, the major variables being losses from perishable goods and parking. The variables linked to factors 3 and 4 are all inputs.

Factor 1 obtained in the PCA allows a positive response to RQ1. This factor groups corporate efficiency and average purchase of loyalty scheme members within $400 \mathrm{~m}$. All the variables related in the same factor with high load factors are meant to correlate strongly. As RQ1 proposes a correlation between the DEA-based corporate efficiency measure and the purchase activity of the loyalty scheme members programme in the trade area, based on the results of Factor 1, RQ1 can be answered positively.

Table 3. PCA rotated component matrix (source: own creation)

\begin{tabular}{|l|c|c|c|c|}
\hline \multicolumn{1}{|c|}{ Variables } & Factor 1 & Factor 2 & Factor 3 & Factor 4 \\
\hline Sales per square metre & $\mathbf{0 . 7 9 9}$ & 0.095 & 0.322 & -0.061 \\
\hline Age of supermarket (years) & $\mathbf{0 . 7 1 1}$ & 0.388 & -0.036 & 0.203 \\
\hline Total sales $(€)$ & $\mathbf{0 . 6 9 4}$ & 0.145 & 0.393 & 0.443 \\
\hline $\begin{array}{l}\text { Average loyalty scheme member } \\
\text { purchase within 400 m }(€)\end{array}$ & $\mathbf{0 . 6 8 5}$ & 0.204 & 0.064 & -0.019 \\
\hline Corporate efficiency & $\mathbf{0 . 6 8 3}$ & 0.186 & 0.476 & -0.179 \\
\hline
\end{tabular}


End of Table 3

\begin{tabular}{|l|c|c|c|c|}
\hline \multicolumn{1}{|c|}{ Variables } & Factor 1 & Factor 2 & Factor 3 & Factor 4 \\
\hline $\begin{array}{l}\text { Primary competitor establishments } \\
\text { within 500 m }\end{array}$ & 0.146 & $\mathbf{0 . 9 2 0}$ & 0.073 & 0.041 \\
\hline $\begin{array}{l}\text { Distance from nearest competitor } \\
(\mathrm{m})\end{array}$ & -0.148 & $\mathbf{- 0 . 8 9 2}$ & -0.046 & 0.017 \\
\hline Population within $400 \mathrm{~m}$ & 0.326 & $\mathbf{0 . 7 2 9}$ & 0.165 & -0.140 \\
\hline Checkout lines & 0.066 & 0.084 & $\mathbf{0 . 8 3 1}$ & 0.043 \\
\hline $\begin{array}{l}\text { Purchases made by loyalty scheme } \\
\text { members (\%) }\end{array}$ & 0.308 & 0.074 & $\mathbf{0 . 6 6 1}$ & 0.092 \\
\hline Losses from perishable goods $(€)$ & 0.245 & 0.058 & -0.045 & $\mathbf{0 . 8 6 6}$ \\
\hline Number of parking spots & -0.381 & -0.224 & 0.211 & $\mathbf{0 . 6 9 7}$ \\
\hline Cumulative \% of variance explained & 38.45 & 53.79 & 64.79 & 72.92 \\
\hline
\end{tabular}

Note: Coefficients greater than 0.5 appear in bold.

\subsection{Classification of supermarkets}

To group the supermarkets, a classification analysis (CA) was performed. Ward's method was chosen to measure the distance between supermarkets, as the idea was to place them within groups that were as internally homogeneous as possible, but with the highest possible heterogeneity between groups (López-Roldán \& Fachelli, 2015). This way, measures to improve efficiency could be tailored to circumstances most similar to those of the supermarkets in each group. After carrying out the CA, the supermarkets were divided into three groups. This was not the first option according to the distances obtained from Ward's method. Nevertheless, after examining the results of different groupings, the 3-group option yielded the best references for benchmarking similar supermarkets. As a result, the supermarkets were grouped into one group of 24, one of 25, and one of 12 .

Table 4 elaborates on the profiles of each group's supermarkets. Group 1 stands out for containing supermarkets with more floor space and parking spots. This group's loyalty scheme member purchases are the lowest of three groups, and the same can be said about its average age. Regarding the trade area characteristics, this group's supermarkets have the lowest figures for nearby population, and a relatively high rate of loyalty scheme member market penetration. Strangely enough, in addition to being the least efficient group, it is also the group whose nearest competitor is farthest away. It can be inferred that such supermarkets are located in sparsely populated areas far from urban cores that require a great deal of floor space and parking places.

The group 2 supermarkets have the highest sales, the highest percentages of purchases made by loyalty scheme members, and are the oldest, which comes with greater management experience and a more solidified presence in the neighbourhood. Not surprisingly, this group has the highest average efficiency. In terms of trade area variables, this group also has the highest rates of average loyalty scheme member purchase within $400 \mathrm{~m}$ and loyalty scheme member market penetration within $400 \mathrm{~m}$. Still, a management variable is 
also seen that exerts a strong influence on efficiency: this group has the greatest losses from perishable goods.

Moving on to the group 3 supermarkets, this group has the lowest total sales figures. On average they are the smallest establishments and have by far the fewest parking spots. These supermarkets' management stands out above all for having the smallest amount of losses from perishable goods. Regarding the group's trade area variables, there are two noteworthy observations. For one, this group has the largest nearby population $(15,685.12)$, though group 2 is not far behind at 14,891.71. Accordingly, this aspect does not seem to be relevant in distinguishing the two. The supermarkets in these two groups are in densely populated, probably urban areas. There is a greater difference in the presence of the primary competitor: group 3 supermarkets have an average of 2.08 competing establishments within a $500 \mathrm{~m}$ radius, whereas those in group 2 have 1.56, and group 3's average distance from its nearest competitor is 266.2 metres, compared to 356.06 for group 2. Therefore, group 3 supermarkets have more competitors within a $500 \mathrm{~m}$ radius, being located closer at the same time, than group 2 supermarkets. Perhaps this explains why group 3 has the lowest rate of loyalty scheme member market penetration.

Table 4. Factor and variable averages for each group (source: own creation)

\begin{tabular}{|c|c|c|c|c|}
\hline \multicolumn{2}{|r|}{ Variables } & Group 1 & Group 2 & Group 3 \\
\hline \multirow{6}{*}{ INPUT } & $\begin{array}{l}\text { Purchases made by loyalty scheme } \\
\text { members }(\%)\end{array}$ & 62.02 & 73.82 & 67.31 \\
\hline & Floor space $\left(\mathrm{m}^{2}\right)$ & $1,217.50$ & $1,097.96$ & 861.08 \\
\hline & Number of parking spots & 52.33 & 33.40 & 7.92 \\
\hline & Losses from perishable goods $(€)$ & $33,129.03$ & $36,379.34$ & $22,159.35$ \\
\hline & Checkout lines & 1.25 & 1.80 & 1.75 \\
\hline & Age of supermarket (years) & 7.75 & 14.60 & 9.92 \\
\hline \multirow{2}{*}{ OUTPUT } & Total sales $(€)$ & $3,008,361.64$ & $5,622,463.45$ & $2,953,105.84$ \\
\hline & Sales per square metre & $2,598.65$ & $5,342.74$ & $3,438.81$ \\
\hline EFFICIENCY & Corporate efficiency & 46.07 & 85.07 & 70.67 \\
\hline \multirow{5}{*}{ TRADE AREA } & Population within $400 \mathrm{~m}$ & $9,209.60$ & $14,891.71$ & $15,685.12$ \\
\hline & $\begin{array}{l}\text { Average loyalty scheme member } \\
\text { purchase within } 400 \mathrm{~m}(€)\end{array}$ & 830.97 & $1,225.07$ & 916.96 \\
\hline & $\begin{array}{l}\text { Loyalty scheme member market } \\
\text { penetration within } 400 \mathrm{~m}(\%)\end{array}$ & 17.22 & 18.20 & 10.69 \\
\hline & $\begin{array}{l}\text { Primary competitor establishments } \\
\text { within } 500 \mathrm{~m}\end{array}$ & 0.75 & 1.56 & 2.08 \\
\hline & $\begin{array}{l}\text { Distance from nearest competitor } \\
(\mathrm{m})\end{array}$ & 501.22 & 358.06 & 266.20 \\
\hline
\end{tabular}

Note: The highest measure for each variable appears in italics. 
Table 5 focuses on the primary objective of the research: grouping the supermarkets based on efficiency. All the supermarkets that lie on the efficiency frontier are in group 2. Group 3, which is half the size of the other two, contains high-efficiency supermarkets (the highest being $98.76 \%$ ). In group 1 , the most efficient supermarket had an efficiency of $79.98 \%$. However, the different average efficiencies clearly show a differentiated typology. Group 2 has an average efficiency of $85.07 \%$, followed by group 3 at $70.67 \%$, and the least efficient, group 1 , with an average efficiency of $46.07 \%$. Keeping in mind that the overall average is $66.89 \%$ and the standard deviation is 25.45 , this classification, in terms of grouping the supermarkets to improve their efficiency, is useful for classifying them based on efficiency. This data allows a positive response to RQ2.

Table 5. Efficiency characteristics per group (source: own creation)

\begin{tabular}{|l|c|c|c|c|}
\hline \multicolumn{1}{|c|}{ Efficiency } & Group 1 & Group 2 & Group 3 & Total \\
\hline Maximum & $79.98 \%$ & $100 \%$ & $98.76 \%$ & $100 \%$ \\
\hline Minimum & $14 \%$ & $35 \%$ & $45.34 \%$ & $14 \%$ \\
\hline Average & $46.07 \%$ & $85.07 \%$ & $70.67 \%$ & $66.89 \%$ \\
\hline $\begin{array}{l}\text { Number of } \\
\text { supermarkets }\end{array}$ & 24 & 25 & 12 & 61 \\
\hline
\end{tabular}

\subsection{Loyalty scheme membership programme management}

Once the three groups of supermarkets were obtained, ANOVA was used to determine whether there were significant differences among them for the variables associated with the loyalty scheme member programme. The three variables were: Purchases made by loyalty scheme members, Average loyalty scheme member purchase within $400 \mathrm{~m}$ and Loyalty scheme member market penetration within $400 \mathrm{~m}$. The first one was included in the DEA model as a management variable. The other two were considered variables of the trade area. Thanks to the GIS, the households of all the loyalty scheme members can be located on a virtual map. Then, drawing up a buffer zone of 400 metres, the average purchase and the total market penetration can be obtained for every supermarket.

First, the normality tests were carried out for the three groups and for the three variables. All the groups passed the Shapiro-Wilk test, except group 3 for the variable Loyalty scheme member market penetration within $400 \mathrm{~m}$ ( $\mathrm{p}=0.045)$. Secondly, the Levene test was used to check the homoscedasticity of the variables (Purchases made by loyalty scheme members (\%): $1.060, \mathrm{p}=0.353$; Average loyalty scheme member purchase within $400 \mathrm{~m}: 0.576, \mathrm{p}=0.566$; Loyalty scheme member market penetration within $400 \mathrm{~m}: 1855, \mathrm{p}=0.166)$. One-way ANOVA results (Table 6) showed that there were significant differences $(\mathrm{p}<0.01$ and $\mathrm{p}<0.05)$ for every variable between the three groups. So, Scheffe's post-hoc tests for group comparison were performed. Table 7 shows the results of the pairwise comparisons.

The most efficient group (Group 2) was the one with the highest average (A) for the three variables. The second most efficient group (Group 3) had an intermediate average for the variables Purchases made by loyalty scheme members and Average loyalty scheme member purchase within $400 \mathrm{~m}$ and the lowest average for Loyalty scheme member market penetration 
within $400 \mathrm{~m}$. Analysing the pairwise comparisons, results showed that: i) there were significant differences between group 1 and group 2 for Purchases made by loyalty scheme members; ii) there were significant differences between group 1 and 2, and between group 2 and 3 for Average loyalty scheme member purchase within $400 \mathrm{~m}$; iii) there were significant differences between group 2 and group 3 for Loyalty scheme member market penetration within $400 \mathrm{~m}$.

This verifies how good management of the loyalty scheme can positively influence the corporate efficiency of a supermarket. As there were significant differences among groups, the local implantation of the loyalty scheme membership programme may become a key element when setting different objectives for internal benchmarking. The variable that establishes the most significant differences between groups is Average loyalty scheme member purchase within $400 \mathrm{~m}$. As a result, RQ3 can be answered positively.

Table 6. One-way ANOVA for variables associated to the loyalty scheme member programme (source: own creation)

\begin{tabular}{|l|c|c|c|c|c|c|c|c|c|}
\hline \multirow{2}{*}{ Variable } & \multicolumn{2}{|c|}{$\begin{array}{c}\text { Group 1 } \\
(\mathrm{n}=24)\end{array}$} & \multicolumn{2}{c|}{$\begin{array}{c}\text { Group 2 } \\
(\mathrm{n}=25)\end{array}$} & \multicolumn{2}{c|}{$\begin{array}{c}\text { Group 3 } \\
(\mathrm{n}=12)\end{array}$} & \multicolumn{3}{c|}{ ANOVA } \\
\cline { 2 - 11 } & $\mathrm{A}$ & $\mathrm{SD}$ & $\mathrm{A}$ & $\mathrm{SD}$ & $\mathrm{A}$ & $\mathrm{SD}$ & $\mathrm{F}$ & $\mathrm{df}$ & Sig \\
\hline $\begin{array}{l}\text { Purchases } \\
\text { made by } \\
\text { loyalty scheme } \\
\text { members (\%) }\end{array}$ & 62.03 & 7.79 & 73.82 & 7.74 & 67.31 & 11.90 & $11.291^{* *}$ & 60 & 0.000 \\
\hline $\begin{array}{l}\text { Average loyalty } \\
\text { scheme member } \\
\text { purchase within } \\
\text { 400 m (€) }\end{array}$ & 830.97 & 272.38 & 1.225 .07 & 240.11 & 916.96 & 301.73 & $14.385^{* *}$ & 60 & 0.000 \\
\hline $\begin{array}{l}\text { Loyalty scheme } \\
\text { member market } \\
\text { penetration } \\
\text { within } 400 \mathrm{~m}(\%)\end{array}$ & 17.22 & 7.98 & 18.20 & 8.28 & 10.69 & 4.69 & $4.219^{*}$ & 60 & 0.019 \\
\hline
\end{tabular}

Note: ${ }^{\star}$ Significant at $5 \% ;{ }^{*}$ Significant at $1 \%$.

Table 7. Post-hoc Scheffe test results for comparing the groups for variables associated with the loyalty scheme member programme (source: own creation)

\begin{tabular}{|c|c|c|c|c|c|c|c|}
\hline \multirow{2}{*}{ Variable } & \multirow{2}{*}{ Group $I$} & \multirow{2}{*}{ Group $J$} & \multirow{2}{*}{$\begin{array}{c}\text { Average } \\
\text { difference } \\
(I-J)\end{array}$} & \multirow{2}{*}{ Std Error } & \multirow{2}{*}{ Sig } & \multicolumn{2}{|c|}{$\begin{array}{l}\text { 95\% Confidence } \\
\text { Interval }\end{array}$} \\
\hline & & & & & & $\begin{array}{l}\text { Lower } \\
\text { Bound }\end{array}$ & $\begin{array}{l}\text { Upper } \\
\text { Bound }\end{array}$ \\
\hline \multirow{3}{*}{$\begin{array}{l}\text { Purchases made } \\
\text { by loyalty scheme } \\
\text { members }(\%)\end{array}$} & 1 & 2 & $-11.80^{* *}$ & 2.49 & 0.000 & -18.05 & -5.55 \\
\hline & 1 & 3 & -5.29 & 3.08 & 0.237 & -13.02 & 2.44 \\
\hline & 2 & 3 & 6.51 & 3.06 & 0.113 & -1.17 & 14.19 \\
\hline \multirow{3}{*}{$\begin{array}{l}\text { Average loyalty } \\
\text { scheme member } \\
\text { purchase within } \\
400 \mathrm{~m}(€)\end{array}$} & 1 & 2 & $-394.10^{* *}$ & 75.90 & 0.000 & -584.79 & -203.41 \\
\hline & 1 & 3 & -85.98 & 93.90 & 0.660 & -321.90 & 149.94 \\
\hline & 2 & 3 & $308.11^{\star *}$ & 93.28 & 0.007 & 73.77 & 542.46 \\
\hline
\end{tabular}


End of Table 7

\begin{tabular}{|l|c|c|c|c|c|c|c|}
\hline \multicolumn{1}{|c|}{ Variable } & Group I & Group J & $\begin{array}{c}\text { Average } \\
\text { difference } \\
(I-J)\end{array}$ & Std Error & Sig & \multicolumn{2}{|c|}{$\begin{array}{c}\text { C5\% Confidence } \\
\text { Interval }\end{array}$} \\
\cline { 5 - 8 } & & 2 & -.98 & 2.17 & 0.903 & -6.44 & 4.48 \\
\hline $\begin{array}{l}\text { Loyer } \\
\text { mound }\end{array}$ & $\begin{array}{c}\text { Upper } \\
\text { Bound }\end{array}$ \\
\cline { 2 - 8 } $\begin{array}{l}\text { market } \\
\text { penetration } \\
\text { within } \\
400 \mathrm{~m}(\%)\end{array}$ & 1 & 3 & 6.53 & 2.69 & 0.060 & -0.23 & 13.29 \\
\cline { 2 - 8 } & 2 & 3 & $7.51^{*}$ & 2.67 & 0.025 & 0.80 & 14.22 \\
\hline
\end{tabular}

Note: ${ }^{\star}$ Significant at $5 \%$; ${ }^{*}$ Significant at $1 \%$.

\section{Theoretical implications}

This research has different theoretical implications, as different gaps that were found in the literature were resolved. First, loyalty scheme membership programmes are related to efficiency. The correlation between the supermarket's DEA-based corporate efficiency with the average loyalty scheme member purchase in the trade area is demonstrated. Until now, the variables related to a loyalty scheme membership programme had not been included in DEA-based studies. Second, the research shows how proper management of this programme can positively influence a supermarket's efficiency. In view of the results, it can be verified how the information extracted from the loyalty scheme member cards can be relevant when evaluating a supermarket. As implementation of the loyalty scheme membership programme within the trade area of the supermarket depends on the local circumstances, the importance of the local factors was examined in depth. Local factors have been included in DEA studies on supermarkets by very few authors. For example, Yoo et al. (1998) considered the competition power index, population density (measured by number of people per firm of total organisations) and total demand (measured by total US retail sales multiplied by the Buying Power Index (BPI)). Thomas et al. (1998) used as location-related costs the occupancy costs, operating expenses, population, households within a 2-mile radius, average annual income of these households and proximity to nearest company store. Barros (2006) used the variable location if the hypermarkets and supermarkets had national or regional coverage. Vyt and Cliquet (2017) also used socio-demographic and competition variables.

Finally, another theoretical contribution is the development of a methodology in which the DEA, GIS, PCA and CA are combined to obtain groups of supermarkets in the same competitive situation to perform the internal benchmarking. Donthu et al. (2005) suggested the DEA model as a solution to the traditional qualitative methods for internal benchmarking processes. The approach presented in this work attempts to improve this methodology. On one hand, the power of DEA and GIS are combined to locate data on a map to obtain the trade area characteristics, including the implementation of the loyalty scheme member programme in this trade area. No studies were found that geolocate information on loyalty scheme cards to assess their potential. After doing so, it was found that the greater or lesser 
implementation of the loyalty scheme member programme can be a working objective to improve efficiency in internal benchmarking processes. On the other hand, groups of supermarkets in much more similar competitive situations can be obtained by adding PCA and CA to DEA. This is a different methodology to tackle the same problem addressed by Vyt and Cliquet (2017). These authors had the limitation that supermarket segmentation was already set by the company. This constitutes a restriction when establishing the benchmarking methodology.

\section{Managerial implications and recommendations}

From a managerial perspective, the classification of the supermarkets obtained can help retailers correct their current internal benchmarking practices. The resulting three-group typology does a good job of classifying the supermarkets in terms of efficiency and points out significant differences in internal management variables and location variables. According to the DEA, the most efficient supermarkets form a cluster with common features such as more experience, higher loyalty scheme member market penetration in the neighbourhood and sales figures. It is precisely in these most efficient supermarkets that the loyalty scheme membership initiative works best. In fact, the three variables associated with the loyalty scheme member cards achieve the highest figures. Again, it can be deduced how good loyalty scheme management can positively influence the efficiency of a supermarket. Nevertheless, it should be emphasised that this CA revealed a particularly influential variable for this group's potential improvement: managing perishable goods. Using only a global analysis without a structural and articulated typology, the supermarkets would very likely have struggled to identify this characteristic. One of the two remaining groups was similar in size to that just described, but its supermarkets stood out for being located far from urban centres, with more parking spots and floor space, and for having opened most recently. These establishments also opened most recently. The third group stands out for better managing perishable goods and for having more competitors in its trade area. These characteristics might partially explain their lower total sales and the lower percentage of purchases made by loyalty scheme members. Although the loyalty scheme membership programme is a key element in the management of a supermarket, its operation also depends on the supermarket's trading area (Meyer-Waarden \& Benavent, 2006).

Retail chains face a big problem when analysing stores located in different environments. With all this information, sales can be tailored to each sales unit depending on its local market conditions. Furthermore, as supermarkets are classified in three different groups, the most efficient units are identified inside every group. In this way, the chain's top management can recognise the best practices of the most efficient supermarkets with a view to transferring them to the least efficient supermarkets in the same competitive situation. Finally, the use of GIS can help companies translate the information collected by the loyalty scheme member cards into spatial information. The location of this information on a virtual map can support companies when making decisions on communication campaigns to strength the loyalty scheme membership programme. For example, managers could detect in what parts of the 
trade area people do not have the loyalty scheme member card or their purchase average is lower. To tackle this problem, managers could prepare a mailing campaign in these localised areas with special offers, discounts, $2 \times 1$ promotions or similar incentives.

\section{Conclusions}

Data envelopment analysis has solidified its position as a tool used to measure efficiency in business units. Its versatility allows it to handle various results (outputs) and classify business units based on the available data. Consequently, it can be applied to many types of companies. Given the peculiar characteristics of the food distribution sector, DEA requires an additional analysis that accounts for each individual trade area, such as demographic features and the proximity of competitors. Combining a structural typology based on current overall management with the trade area's particular features, distinctions can be made to fine-tune the study for improved efficiency. In this way, upon starting a benchmarking process, supermarkets in the same competitive situation can be compared and different objectives can be set based on that situation. In this work, the methodology has been validated in the case of one of Spain's five largest supermarket chains. A PCA and a CA were performed on a series of internal management variables from 61 locations for which DEA had been used to calculate efficiency and to which multiple trade area variables were added, some of them related to the supermarket chain's loyalty scheme membership programme. These latter variables described the local implantation of the loyalty scheme member programme and were revealed as key elements for the efficiency of the supermarket and when setting goals for internal benchmarking of the supermarket chain. This was relevant for the supermarket chain, as this loyalty card represents a key element in its strategy.

It can be concluded that loyalty scheme membership programmes have a positive effect on supermarket's efficiency. Methodologically, benchmarking processes are also improved by integrating DEA with GIS, PCA and CA. This is a powerful approach that can be used to integrate data input, spatial analysis and visualisation. Future research into improving measures of efficiency would do well to include new variables in terms of both management and trade area. For example, loyalty scheme member cards also collect information about the shopping basket. Data on the different product categories could also be introduced. The integration of smart technologies to provide superior services may also be interesting from the management perspective. The use of GIS can help improve the data collected from the trade area. Including geo-demographic variables in more complex regression models might also be worthwhile. Finally, there are two limitations in this research. One is that corporate efficiency is calculated for one specific year (2017). Tracking of the supermarkets' efficiency over time would provide useful insights for the chain's top management. Another limitation is that average annual income of the population in the trade area is not considered. This variable is not provided by loyalty scheme membership programmes, but could be deduced from census data and using GIS. In any case, integrating DEA with typological classification tools that include geo-demographic variables makes a significant contribution to efforts to improve efficiency, as it helps develop more similar and homogeneous supermarket profiles. 
This contribution could be critical for nationwide chains, as it provides marketing profiles that are more adapted to local circumstances, thus allowing companies to better establish internal benchmarking objectives.

\section{Acknowledgements}

The authors would like to thank the Consum-Universitat Politècnica de València Chair (Cátedra) for its collaboration in this study.

\section{Funding}

No funding agency grants.

\section{Author contributions}

$\mathrm{AB}$ and $\mathrm{JB}$ conceived the study and were responsible for the design of the data analysis. JB and $\mathrm{CE}$ were responsible for data collection. $\mathrm{AB}$ and $\mathrm{TB}$ analyzed the data. $\mathrm{CE}$ and JB were responsible for data interpretation. $\mathrm{TB}$ and $\mathrm{AB}$ wrote the paper.

\section{Disclosure statement}

Authors do not have any competing financial, professional, or personal interests from other parties.

\section{References}

Álvarez-Rodríguez, C., Martín-Gamboa, M., \& Iribarren, D. (2019). Combined use of Data Envelopment Analysis and Life Cycle Assessment for operational and environmental benchmarking in the service sector: A case study for grocery stores. Science of the Total Environment, 667, 799-808. https://doi.org/10.1016/j.scitotenv.2019.02.433

Applebaum, W., \& Cohen, S. B. (1961). The dynamics of store trading areas and market equilibrium. Annals of the Association of American Geographers, 51(1), 73-101. https://doi.org/10.1111/j.1467-8306.1961.tb00369.x

Banker, R. D., Charnes, A., \& Cooper, W. W. (1984). Some models for estimating technical and scale inefficiencies in data envelopment analysis. Management Science, 30(9), 1078-1092. https://doi.org/10.1287/mnsc.30.9.1078

Barros, C. P. (2006). Efficiency measurement among hypermarkets and supermarkets and the identification of the efficiency drivers. A case study. International Journal of Retail \& Distribution Management, 34(2), 135-154. https://doi.org/10.1108/09590550610649795

Barros, C. P., \& Alves, C. A. (2003). Hypermarket retail store efficiency in Portugal. International Journal of Retail \& Distribution Management, 31(11), 549-560. https://doi.org/10.1108/09590550310503285

Barros, C. P., \& Alves, C. A. (2004). An empirical analysis of productivity growth in a Portuguese retail chain using Malmquist productivity index. Journal of Retailing and Consumer Services, 11(5), 269-278. https://doi.org/10.1016/S0969-6989(03)00053-5 
Baviera-Puig, A., Buitrago-Vera, J., \& Escribá-Pérez, C. (2016). Geomarketing models in supermarket location strategies. Journal of Business Economics and Management, 17(6), 1205-1221. https://doi.org/10.3846/16111699.2015.1113198

Brønn, C., \& Brønn, P. S. (2005). Reputation and organizational efficiency: A data envelopment analysis study. Corporate Reputation Review, 8(1), 45-58. https://doi.org/10.1057/palgrave.crr.1540238

Byrom, J., Hernández, T., Bennison, D., \& Hooper, P. (2001). Exploring the geographical dimension in loyalty card data. Marketing Intelligence \& Planning, 19(3), 162-170. https://doi.org/10.1108/02634500110391708

Cachero-Martínez, S., \& Vázquez-Casielles, R. (2017). Living positive experiences in store: how it influences shopping experience value and satisfaction. Journal of Business Economics and Management, 18(3), 537-553. https://doi.org/10.3846/16111699.2017.1292311

Charnes, A., Cooper, W. W., \& Rhodes, E. (1978). Measuring the efficiency of decision-making units. European Journal of Operational Research, 2(6), 429-444.

https://doi.org/10.1016/0377-2217(78)90138-8

Chaudhuri, M., Voorhees, C. M., \& Beck, J. M. (2019). The effects of loyalty program introduction and design on short- and long-term sales and gross profits. Journal of the Academy of Marketing Science, 47(4), 640-658. https://doi.org/10.1007/s11747-019-00652-y

De Jorge, J. (2006). Regional regulation analysis of performance in Spanish retailing. International Journal of Retail and Distribution Management, 34(10), 773-793. https://doi.org/10.1108/09590550610691356

Donthu, N., \& Yoo, B. (1998). Retail productivity assessment using data envelopment analysis. Journal of Retailing, 74(1), 89-105. https://doi.org/10.1016/S0022-4359(99)80089-X

Donthu, N., Hershberger, E. K., \& Osmonbekov, T. (2005). Benchmarking marketing productivity using data envelopment analysis. Journal of Business Research, 58(11), 1474-1482. https://doi.org/10.1016/j.jbusres.2004.05.007

Drèze, X., \& Nunes, J. C. (2009). Feeling superior: The impact of loyalty program structure on consumers' perceptions of status. Journal of Consumer Research, 35(6), 890-905. https://doi.org/10.1086/593946

Emrouznejad, A., \& Yang, G. L. (2018). A survey and analysis of the first 40 years of scholarly literature in DEA: 1978-2016. Socio-Economic Planning Sciences, 61, 4-8. https://doi.org/10.1016/j.seps.2017.01.008

Felício, J. A., \& Galindo, M. P. (2015). Family characteristics and governance of small and medium-sized family firms. Journal of Business Economics and Management, 16(6), 1069-1084. https://doi.org/10.3846/16111699.2012.747446

Gandhi, A., \& Shankar, R. (2014). Efficiency measurement of Indian retailers using Data Envelopment Analysis. International Journal of Retail and Distribution Management, 42(6), 500-520. https://doi.org/10.1108/IJRDM-10-2012-0094

Goldman, A. (1992). Evaluating the performance of the Japanese distribution system. Journal of Retailing, 68(1), 11-39.

Goss, J. (1995). We know who you are and we know where you live: The instrumental rationality of geodemographic systems. Economic Geography, 71(2), 171-198. https://doi.org/10.2307/144357

Grewal, D., Levy, M., Mehrotra, A., \& Sharma, A. (1999). Planning merchandising decisions to account for regional and product assortment differences. Journal of Retailing, 75(3), 405-424. https://doi.org/10.1016/S0022-4359(99)00015-9

Hanousek, J., Kocenda, E., \& Shamsur, A. (2015). Corporate efficiency in Europe. Journal of Corporate Finance, 32, 24-40. https://doi.org/10.1016/j.jcorpfin.2015.03.003

Harris, R., Sleight, P., \& Webber, R. (2005). Geodemographics, GIS and neighbourhood targeting. John Wiley \& Sons. 
Herranz, R., Estévez, P., Oliva, M., \& Dé, R. (2017). Leveraging financial management performance of the Spanish aerospace manufacturing value chain. Journal of Business Economics and Management, 18(5), 1005-1022. https://doi.org/10.3846/16111699.2017.1357655

Ingene, C. A. (1984). Productivity and functional shifting in spatial retailing: Private and social perspectives. Journal of Retailing, 60, 15-36.

Kang, J., Alejandro, T. B., \& Groza, M. D. (2015). Customer-company identification and the effectiveness of loyalty programs. Journal of Business Research, 68(2), 464-471. https://doi.org/10.1016/j.jbusres.2014.06.002

Kato, A. (2015). Productivity and characteristics of firms: An application of a bootstrapped data envelopment analysis to Japanese firm-level data. Journal of Asia-Pacific Studies, 24, 145-159.

Kim, H-Y., Lee, J. Y., Choi, D., Wu, J., \& Johnson, K. K. (2013). Perceived benefits of retail loyalty programs: Their effects on program loyalty and customer loyalty. Journal of Relationship Marketing, 12(2), 95-113. https://doi.org/10.1080/15332667.2013.794100

Kumar, V., \& Petersen, J. A. (2005). Using a customer-level marketing strategy to enhance firm performance: A review of theoretical and empirical evidence. Journal of the Academy of Marketing Science, 33(4), 504-519. https://doi.org/10.1177/0092070305275857

Kumar, V., \& Shah, D. (2004). Building and sustaining profitable customer loyalty for the 21 st century. Journal of Retailing, 80(4), 317-329. https://doi.org/10.1016/j.jretai.2004.10.007

Lao, Y., \& Liu, L. (2009). Performance evaluation of bus lines with data envelopment analysis and geographic information systems. Computers, Environment and Urban Systems, 33(4), 247-255. https://doi.org/10.1016/j.compenvurbsys.2009.01.005

Leenheer, J., Van Heerde, H. J., Bijmolt, T. H., \& Smidts, A. (2007). Do loyalty programs really enhance behavioral loyalty? An empirical analysis accounting for self-selecting members. International Journal of Research in Marketing, 24(1), 31-47. https://doi.org/10.1016/j.ijresmar.2006.10.005

Lewis, H. F., \& Sexton, T. R. (2004). Data envelopment analysis with reverse inputs and outputs. Journal of Productivity Analysis, 21, 113-132. https://doi.org/10.1023/B:PROD.0000016868.69586.b4

Li, Y., \& Liu, L. (2012). Assessing the impact of retail location on store performance: A comparison of Wal-Mart and Kmart stores in Cincinnati. Applied Geography, 32(2), 591-600. https://doi.org/10.1016/j.apgeog.2011.07.006

López-Roldán, P. (1996). La construcción de tipologías: Metodologías de análisis. Papers, 48, 9-29. https://doi.org/10.5565/rev/papers.1811

López-Roldán, P., \& Fachelli, S. (2015). Análisis de clasificación. In P. López-Roldán \& S. Fachelli (Eds.), Metodología de la Investigación Social Cuantitativa (1a edición, versión 2). Bellaterra: Dipòsit Digital de Documents, Universitat Autónoma de Barcelona. http://ddd.uab.cat/record/142929

López-Roldán, P., \& Fachelli, S. (2016). Análisis factorial. In P. López-Roldán \& S. Fachelli (Eds.), Metodología de la Investigación Social Cuantitativa (1a edición, versión 3). Bellaterra: Dipòsit Digital de Documents, Universitat Autónoma de Barcelona. http://ddd.uab.cat/record/142928

Meyer-Waarden, L. (2007). The effects of loyalty programs on customer lifetime duration and share of wallet. Journal of Retailing, 83(2), 223-236. https://doi.org/10.1016/j.jretai.2007.01.002

Meyer-Waarden, L. (2008). The influence of loyalty programme membership on customer purchase behavior. European Journal of Marketing, 42(1/2), 87-114. https://doi.org/10.1108/03090560810840925

Meyer-Waarden, L., \& Benavent, C. (2006). The impact of loyalty programmes on repeat purchase behaviour. Journal of Marketing Management, 22(1), 61-88. https://doi.org/10.1362/026725706776022308

Mimouni-Chaabane, A., \& Volle, P. (2010). Perceived benefits of loyalty programs: Scale development and implications for relational strategies. Journal of Business Research, 63(1), 32-37. https://doi.org/10.1016/j.jbusres.2009.01.008

Moreno, J. (2010). Productivity growth of European retailers: A benchmarking approach. Journal of Economic Studies, 37(3), 288-313. https://doi.org/10.1108/01443581011061285 
Mostafa, M. (2009). Benchmarking the US specialty retailers and food consumer store using data envelopment analysis. International Journal of Retail and Distribution Management, 37(8), 661-679. https://doi.org/10.1108/09590550910966178

Neves Bezerra de Melo, F. L., Sampaio, R. M. B., \& Sampaio, L. M. B. (2018). Efficiency, productivity gains, and the size of Brazilian supermarkets. International Journal of Production Economics, 197, 99-111. https://doi.org/10.1016/j.ijpe.2017.12.016

Nielsen. (2018). Retailers database. Nielsen Company.

Nitkiewicz, T., Pachura, P., \& Reid, N. (2014). An appraisal of regional intellectual capital performance using Data Envelopment Analysis. Applied Geography, 53, 246-257. https://doi.org/10.1016/j.apgeog.2014.06.011

Noordhoff, C., Pauwels, P., \& Odekerken-Schröder, G. (2004). The effect of customer card programmes: A comparative study in Singapore and The Netherlands. International Journal of Service Industry Management, 15(4), 351-364. https://doi.org/10.1108/09564230410552040

Pantano, E., Priporas, C., \& Dennis, C. (2018). A new approach to retailing for successful competition in the new smart scenario. International Journal of Retail \& Distribution Management, 46(3), 264-282. https://doi.org/10.1108/IJRDM-04-2017-0080

Patel, G. N., \& Pande, S. (2013). Measuring the performance of pharmacy stores using discretionary and non-discretionary variables. Opsearch, 50(1), 25-41. https://doi.org/10.1007/s12597-012-0095-0

Roig-Tierno, N., Baviera-Puig, A., Buitrago-Vera, J., \& Escribá-Pérez, C. (2018). Assessing food retail competitors with a multi-criteria GIS-based method. Economía Agraria y Recursos Naturales - Agricultural and Resource Economics, 18(1), 05-22. https://doi.org/10.7201/earn.2018.01.01

Roig-Tierno, N., Baviera-Puig, A., Buitrago-Vera, J., \& Mas-Verdu, F. (2013). The retail site location decision process using GIS and the analytical hierarchy process. Applied Geography, 40(1), 191-198. https://doi.org/10.1016/j.apgeog.2013.03.005

Sanjuan, N., Ribal, J., Clemente, G., \& Fenollosa, M. L. (2011). Measuring and improving eco-efficiency using Data Envelopment Analysis. A case study of Mahón-Menorca Cheese. Journal of Industrial Ecology, 15(4), 614-628. https://doi.org/10.1111/j.1530-9290.2011.00347.x

Sellers-Rubio, R., \& Mas-Ruiz, F. (2006). Economic efficiency in supermarkets: evidences in Spain. International Journal of Retail and Distribution Management, 34(2), 155-171. https://doi.org/10.1108/09590550610649803

Sellers-Rubio, R., \& Mas-Ruiz, F. (2009). Technical efficiency in the retail food industry. European Journal of Marketing, 43(5/6), 652-669. https://doi.org/10.1108/03090560910946981

Steinhoff, L., \& Palmatier, R. W. (2016). Understanding loyalty program effectiveness: Managing target and bystander effects. Journal of the Academy of Marketing Science, 44(1), 88-107. https://doi.org/10.1007/s11747-014-0405-6

Tat Keh, H., \& Chu, S. (2003). Retail productivity and scale economies at the firm level: A DEA approach. Omega, 31(2), 75-82. https://doi.org/10.1016/S0305-0483(02)00097-X

Thomas, R. R., Barr, R. S., Cron, W. L., \& Slocum, J. W. (1998). A process for evaluating retail store efficiency: A restricted DEA approach. International Journal of Research in Marketing, 15(5), 487-503. https://doi.org/10.1016/S0167-8116(98)00021-4

Tomlinson, R. (2007). Thinking about GIS. GIS planning for managers ( $3^{\text {rd }}$ ed.). ESRI Press.

Uyar, A., Bayyurt, N., Dilber, M., \& Karaca, V. (2013). Evaluating operational efficiency of a bookshop chain in Turkey and identifying efficiency drivers. The International Journal of Retail and Distribution Management, 41(5), 331-347. https://doi.org/10.1108/IJRDM-01-2012-0001

Vyt, D., \& Cliquet, G. (2017). Towards a fairer manager performance measure: a DEA application in the retail industry. The International Review of Retail, Distribution and Consumer Research, 27(5), 450-467. https://doi.org/10.1080/09593969.2017.1383293 
Yoo, B., Donthu, N., \& Pilling, B. C. (1998). Channel efficiency. Journal of Marketing Channels, 6(3-4), 1-15. https://doi.org/10.1300/J049v06n03_01

Yu, W., \& Ramanathan, R. (2008). An assessment of operational efficiencies in the UK retail sector. International Journal of Retail and Distribution Management, 36(11), 861-882. https://doi.org/10.1108/09590550810911656

Zheka, V. (2005). Corporate governance, ownership structure and corporate efficiency: The case of Ukraine. Managerial and Decision Economics, 26(7), 451-460. https://doi.org/10.1002/mde.1258

Zhu, J. (2014). Quantitative models for performance evaluation and benchmarking: Data Envelopment Analysis with Spreadsheets ( $3^{\text {rd }}$ ed.). Springer International Publishing. 